\title{
Neuro-ophthalmology in the Geriatric Eye
}

\author{
Subhan Tabba, ${ }^{1}$ Yi-Hsien Yeh, ${ }^{2}$ Ashwini Kini,, ${ }^{3}$ Bayan Al Othman, ${ }^{3}$ and Andrew G Lee $^{2-7}$ \\ 1. McGovern Medical School, The University of Texas Health Science Center at Houston, Houston, TX, USA; 2. Texas A\&M College of Medicine, Bryan, \\ TX, USA; 3. Department of Ophthalmology, Blanton Eye Institute, Houston Methodist Hospital, Houston, TX, USA; 4. The Houston Methodist Research \\ Institute, Houston Methodist Hospital, Houston, TX, USA; 5. Departments of Ophthalmology, Neurology, and Neurosurgery, Weill Cornell Medicine, \\ New York, NY, USA; 6. Department of Ophthalmology, University of Texas Medical Branch, Galveston, TX, USA; 7. University of Texas MD Anderson \\ Cancer Center, Houston, TX, USA
}

DOI: https://doi.org/10.17925/USOR.2020.13.1.30

T here are several neuro-ophthalmic conditions that predominantly affect the elderly population: some that need immediate and prompt recognition for recovery, and some that run a more benign and prolonged course. Timely recognition, diagnosis, and treatment will not only improve vision, but will greatly improve quality of life for the elderly. The purpose of this article is to highlight some of the common eye conditions that a general ophthalmologist or a primary care provider needs to be aware of in order to help treat or refer these patients for further management.

\section{Keywords}

Presbyopia, posterior cortical atrophy, giant cell arteritis, sagging eye syndrome, non-arteritic ischemic optic neuropathy, progressive supranuclear palsy

Disclosures: Subhan Tabba, Yi-Hsien Yeh, Ashwini Kini, Bayan Al Othman, and Andrew G Lee have no financial or non-financial relationships or activities to declare in relation to this article.

Review Process: Double-blind peer review.

Compliance with Ethics: This study involves a review of the literature and did not involve any studies with human or animal subjects performed by any of the authors.

Authorship: The named authors meet the International Committee of Medical Journal Editors (ICMJE) criteria for authorship of this manuscript, take responsibility for the integrity of the work as a whole, and have given final approval for the version to be published.

Access: This article is freely accessible at tOuChOPHTHALMOLOGY.COM

(C) Touch Medical Media 2020

Received: July 29, 2019

Accepted: May 12, 2020

Published Online: June 11, 2020

Citation: US Ophthalmic Review. 2020;13(1):30-3

Corresponding Author: Andrew G Lee,

Blanton Eye Institute, Houston Methodist Hospital, 6560 Fannin Street, Suite 450, Houston, TX 77030, USA.

E: aglee@houstonmethodist.org

Support: No funding was received in

the publication of this article.
As the percentage of elderly people that make up the population of the USA grows, it is imperative to shift our focus on how to best address their needs and outline an approach to the geriatric eye. This review describes common physiologic and pathologic conditions affecting the aging eye including presbyopia, posterior cortical atrophy, giant cell arteritis (GCA), sagging eye syndrome, strokes, progressive supranuclear palsy (PSP), and non-arteritic anterior ischemic optic neuropathy (NAION).

\section{Presbyopia}

Accommodation is the ability of the native lens and zonules to increase their refractive power to keep objects that are closer to the eye in focus on the retina, and vice versa. ${ }^{1}$ Presbyopia is the gradual age-related loss of the ability to accommodate, and the most significant loss of this ability occurs after approximately 50 years of age. Under the age of 20 , the normal accommodative power of the eye is $7-10$ diopters, but by age 50 , it decreases to about 0.5 diopters. ${ }^{2}$ Symptoms of presbyopia are usually first reported around 42-44 years of age, and there is considerable reduction in amplitude of accommodation by age 50-55 years. Patients typically present with blurred vision at near and asthenopia (e.g., squinting, headaches secondary to eye strain), increased light requirement, and the need to work from progressively greater distances. ${ }^{1,3}$ To diagnose accommodative insufficiency, a clinical exam measuring corrected near and distance visual acuities needs to be carried out to measure refractive error and functional capacity at near distances. Cycloplegic retinoscopy and refraction might uncover latent hyperopic refractive error that might contribute to symptoms of accommodative insufficiency, including presbyopia.

While presbyopia is inherent to the process of aging, the exact pathophysiology of it is still ill defined. ${ }^{1}$ Although the exact cause is unknown, there have been two categories of thoughts that have developed as possible explanations for the development of presbyopia: Ienticular and extralenticular. ${ }^{4}$ The lenticular theories suggest that presbyopia results from structural changes (e.g., sclerosis of the nuclear lens tissue, decreased distance between ciliary muscle and the lens equator, decreased elasticity of the lens capsule) that occur in the lens, capsule or zonular fibers. Extralenticular theories suggest that presbyopia may result from ciliary muscle dysfunction, loss of elasticity in the posterior zonules or choroid, and/or decreasing resistance of the vitreous humor against the accommodating lens capsule. ${ }^{4-6}$ Although age is the primary factor determining the development of presbyopia, other factors that may cause premature onset of presbyopia include systemic disease, medications, and trauma. ${ }^{7.8}$

Presbyopia is preferably managed with corrective glasses (e.g., bifocals, progressive lenses) for near work; however, surgical options may also be helpful (e.g., intraocular multifocal lenses, and corneal inlays). ${ }^{8}$ These interventions may increase the depth of the field, but at the possible cost of loss of contrast or best-corrected visual acuity. 


\section{Posterior cortical atrophy-visual variant of Alzheimer's disease or Benson's syndrome}

Posterior cortical atrophy (PCA) is a neurodegenerative syndrome in which patients develop progressive higher order visual function loss, but could have relatively unaffected cognition. PCA presents in patients in their mid-50s or older, and there are generally no initial abnormalities noted on routine ophthalmic and neurologic exam. Some studies have reported a slight female bias, ${ }^{11,12}$ but others have found no gender preference. ${ }^{13,14}$ symptoms usually have visuospatial manifestations, such as difficulty with reading, navigating, numeracy, and interpretation of complex scenery despite normal visual acuity and normal structural eye exam, or disproportionate to their underlying ocular morbidity including cataract, age-related macular degeneration etc. Over time, a homonymous hemianopsia or cortical visual loss may develop. Tests that may help indicate PCA that can be conducted in the clinic include the clock-drawing test for visuospatial deficits, and the cookie theft test (simultagnosia). Making use of Ishihara color plates may also help narrow down the diagnosis, as patients with PCA may be unable to verbalize the embedded number, despite the ability to identify the colors or even the ability to trace the number with their finger (simultagnosia).

Diagnosis may be made with radiographic findings (e.g., magnetic resonance imaging [MRI], positron emission tomography) suggestive of posterior (parieto-occipital) brain atrophy. There may be relative sparing of the medial temporal lobe. ${ }^{12,15}$ The pathological basis for this condition is analogous to that of Alzheimer's disease as patients with PCA are noted to have neurofibrillary tangles and amyloid plaques on autopsy.11,14 PCA and Alzheimer's disease may also result in cerebrospinal fluid containing phosphorylated tau and beta amyloid. ${ }^{16-19}$ The genetics of the condition are being studied and a large genome-wide association study of 302 patients with PCA has identified three loci (SEMA3C, CNTNAP5, and FAM46A) of interest. ${ }^{20}$

There have been two proposed subtypes of PCA: the occipito-parietal and the ventral, based on which cortical visual stream is affected by the neurodegeneration. ${ }^{21-24}$ When the occipito-parietal stream is affected, then it results in visuospatial complaints, and when the ventral stream is affected it results in visuo-perceptive difficulties (e.g., visual agnosia, simultagnosia, prosopagnosia, and agraphia). However, some researchers argue that PCA is a continuum, rather than consisting of two distinct subtypes. ${ }^{12,25}$ Patients with PCA typically progress to develop episodic memory loss, and linguistic and executive dysfunction. ${ }^{11,12,26}$

Management is mostly supportive but there is a heavy focus on improving the quality of life and maintaining the activities of daily living in these patients via occupational therapy and visual rehabilitation. Acetylcholinesterase inhibitors (e.g., donepezil, galantamine, rivastigmine) are used for treatment of Alzheimer's disease and there have been some case reports suggesting that they may be useful in the treatment of PCA. ${ }^{25,27}$

\section{Giant cell arteritis-temporal arteritis}

GCA is the most common vasculitis in patients over the age of 50 and has a higher prevalence in Caucasians, specifically those of Scandinavian and Northern European descent. ${ }^{28-31}$ The average age of presentation is 72.5 years in women and 70.3 years in men, and it is twice as common in women. $29,31,32$ GCA is a granulomatous inflammation of medium- to large-sized vessels. The most common vessels that are implicated in this condition are the branches of external carotid, internal carotid, and the vertebral arteries. ${ }^{33}$ Involvement of the ophthalmic artery as well as the posterior ciliary arteries are responsible for the severe visual morbidity in affected patients. GCA typically presents to ophthalmology with acute unilateral or bilateral vision loss ${ }^{34,35}$ and associated symptoms of headache (temporal or occipital), ${ }^{36,37}$ scalp tenderness, jaw claudication, diplopia, myalgias, and constitutional symptoms. ${ }^{38}$ GCA is considered an ophthalmologic emergency because if left untreated it may progress to permanent vision loss (usually secondary to arteritic anterior ischemic optic neuropathy, but also to posterior ischemic optic neuropathy, or central retinal artery occlusion). ${ }^{34}$ Although the gold standard for diagnosing GCA is the temporal artery biopsy, the results of these biopsies may be falsely negative due to GCA containing skip lesions. Erythrocyte sedimentation rate and C-reactive peptide lab tests can support the diagnosis of GCA. ${ }^{36,39-41}$

The exact cause of GCA is still unknown; some studies conducted in a stable population appeared to show cyclic fluctuation in the incidence of GCA, supporting an infectious (Chlamydia pneumoniae, varicella, parvovirus B19), environmental, or genetic cause of GCA, ${ }^{36,42-44}$ while others suggest that GCA is an endogenous inflammatory event caused by an element in the arterial wall. ${ }^{45}$ In response to the unknown initiating event, T cells in the vessels upregulate macrophages, causing a granulomatous immune reaction. This reaction results in the destruction and remodeling of the arterial wall and progresses to occluding the lumen, resulting in the ischemic symptoms of GCA. ${ }^{46}$

Corticosteroids are the mainstay of treatment upon initial diagnosis. ${ }^{47}$ In GCA, interleukin-6 (IL-6) is one of many inflammatory mediators that is predominantly upregulated in the inflamed arteries. There has been a recent trial investigating the benefits of tocilizumab (an anti-IL-6) in patients with refractory GCA or those with significant steroid-related side effects. Tocilizumab helps to taper steroid treatment faster while keeping the inflammation in GCA under control. ${ }^{48,49}$ While the effectiveness of treatment is highly dependent on how quickly it was initiated, up to one third of the treated cases may show some level of improvement in visual acuity, however, prognosis in affected eyes is usually poor. ${ }^{50-53}$

\section{Sagging eye syndrome}

Sagging eye syndrome is an increasingly recognized cause of strabismus in the elderly population. The extraocular muscles are surrounded by connective tissue that functionally serves to support and act as pulleys for the extraocular muscles. Age-related degeneration of this connective tissue results in "sagging" and can cause esotropia, hypotropia, supraduction deficit and/or strabismus. An orbital MRI may show the lateral rectus-superior rectus connective tissue sagging. ${ }^{54}$ Patients who are not experiencing double vision are typically managed expectantly. Otherwise, patients are offered prisms to manage the double vision. There are also surgical options for treatment of sagging eye syndrome if they do not respond to, or do not want, prism therapy.

\section{Strokes}

The eyes and brain share a vascular supply, so transient vision loss can be a warning sign for an imminent stroke and should be treated as thus. ${ }^{5.5}$ Amaurosis fugax is commonly caused by carotid insufficiency and nearly $50 \%$ of these cases progress to cause a stroke within 3 years. Hypertension, diabetes, hypercholesterolemia, and cardiovascular risk factors increase overall risk for stroke. New-onset neurologic deficits, such as monocular 
vision loss from arterial occlusion, binocular acute onset homonymous field defect, acute onset binocular horizontal or vertical diplopia including transient vision loss, are red flags for stroke and need to be evaluated by stroke neurology for detailed imaging and stroke work-up, as well as management of systemic risk factors.

\section{Progressive supranuclear palsy- Steele-Richardson-Olszewski syndrome}

PSP is a tauopathy that typically presents in adults older than 40 years of age, ${ }^{56,57}$ but can easily be misdiagnosed as other neurodegenerative conditions like Parkinson's disease. ${ }^{58}$ Patients with PSP usually present with progressive supranuclear vertical ophthalmoplegia, that is more apparent in the downgaze, and postural instability. ${ }^{59-61}$ These symptoms can be attributed to the degeneration of neurons secondary to accumulation of tau proteins in the brainstem and basal ganglia, superior to the nuclei that control eye movement. ${ }^{62,63} \mathrm{An}$ MRI may be performed to rule out other causes for the symptoms such as cerebrovascular disease, hydrocephalus, and tumors. An MRI for PSP may reveal atrophy of the midbrain, poor differentiation of the substantia nigra and atrophy of the putamen and/or red nucleus, commonly referred to as the "hummingbird sign". ${ }^{64}$ The exact cause of PSP is unknown but it has been attributed to arsenic, and genetic mutations that result in neurofibrillary tangles. ${ }^{65-68}$

While there are no effective medications to treat PSP, symptomatic treatment and physical therapy for fall reduction should be offered to patients. Dopaminergic replacement therapy may mildly relieve symptoms temporarily. Antidepressants are helpful in treating associated symptoms of apathy or depression. Amitriptyline may be used to alleviate the insomnia and gabapentin may be used to treat dystonic pain. Mirror-prism glasses may help the downgaze palsy and botulinum toxin injections may reduce blepharospasm, dystonia, and retrocollis. ${ }^{69,70}$ The prognosis for PSP is poor, with average time of survival from diagnosis being 5-9 years. ${ }^{70,71}$

\section{Non-arteritic ischemic optic neuropathy}

NAION is the most common acute optic neuropathy in patients over 50 years old. ${ }^{22-74}$ Patients typically present with acute, unilateral painless vision loss or blurring, typically sectorally in the inferior visual field.
Patients have decreased visual acuity, visual field defects, relative afferent pupillary defect, and a swollen optic nerve on physical exam. ${ }^{75-77}$ NAION is typically associated with vasculopathic risk factors, but other factors have also been proposed (e.g., sleep apnea syndrome, ${ }^{78,79}$ interferon alpha medication, 80,81 phosphodiesterase inhibitors,, 82 and optic disc drusen). ${ }^{83-85}$ The pathophysiological mechanism has been suggested to be that NAION is a result of insufficient circulation in the short posterior ciliary arteries. ${ }^{86-89}$

There is no clinically proven treatment for NAION. The role for anticoagulants and antiplatelet agents, and use of steroids in the therapy of NAION, however, is without proven benefits. ${ }^{90,91}$ Control of systemic risk factors including diabetes, hypertension, and hyperlipidemia with regular exercise, aspirin (unless contraindicated), and dietary modification may be advised to the patient to reduce the risk of involvement of the other eye. The vision changes associated with NAION typically stabilize within 2 months of onset. ${ }^{76}$ Currently there are ongoing clinical trials for therapeutic intervention in NAION, both in the acute and chronic setting, and the options of enrollment in a trial may be discussed with the patient.. ${ }^{2}$ The prognosis for visual recovery is better in younger patients. ${ }^{74}$

\section{Summary}

The ocular conditions that present in the elderly are very distinct compared with the pathologies presenting in the younger population. Most general practitioners are aware of some common problems, such as cataract and glaucoma, and refer them to ophthalmologists. However, there are some less well-known neuro-ophthalmic conditions which, if not identified in a timely manner, can lead to irreversible vision loss and compromise quality of life for the elderly, many of whom are already dealing with multiple comorbidities. Several recent studies have also linked vision loss with depression and earlier onset of neuro-cognitive disorders. Identification and timely referrals can sometimes salvage vision, especially when time is a crucial factor, as in GCA. Some conditions, such as NAION, are associated with multiple systemic risk factors that need to be adequately controlled to the reduce risk of involvement of the other eye. These conditions require a multidisciplinary approach, requiring input from primary care physicians, ophthalmologists, and also neurologists. $\square$
1. American Optometric Association (AOA). Quick reference guide: care of the patient with hyperopia. 2010. Available at: www.aoa. org/documents/optometrists/QRG-16.pdf (accessed June 3, 2020).

2. Anderson $\mathrm{HA}$, Hentz $\mathrm{G}$, Glasser A, et al. Minus-lens-stimulated accommodative amplitude decreases sigmoidally with age: a study of objectively measured accommodative amplitudes from age 3. Invest Ophthalmol Vis Sci. 2008:49:2919-26.

3. Wick B. Vision training for presbyopic nonstrabismic patients. Am J Optom Physiol Opt. 1977;54:244-7.

4. Croft MA, Nork TM, MCDonald JP, et al. Accommodation and presbyopia: movements of the accommodative apparatus in the presence of the iris and lens. Invest Ophthalmol Vis SCi. 2017; $58: 2477$.

5. Glasser A, Kaufman PL. The mechanism of accommodation in primates. Ophthalmology. 1999;106:863-72.

6. Navarro R. Optics of the crystalline lens and accommodative response. Presented at: The XXXV congress of the European Society of Cataract and Refractive Surgeons (ESCRS), Lisbon, Portugal, October 7-11, 2017. Available at: https://digital.csic. es/bitstream/10261/149516/1/ESCRS2016_RNavarroLens.pdf (accessed May 13, 2020)

7. Mian SI. Visual impairment in adults: refractive disorders and presbyopia. 2019. Available at: www.uptodate.com/contents/ visual-impairment-in-adults-refractive-disorders-and-presbyopia (accessed May 13, 2020).

8. Santaella R, Afshari N. Presbyopia-correcting intraocular lenses: one lens does not fit all. Curr Opin Ophthalmol. 2010;21:1-3.

. Torricelli AA, Junior JB, Santhiago MR, Bechara SJ. Surgical management of presbyopia. Clin Ophthalmol. 2012;6:1459-66.

10. Lichtinger A, Rootman DS. Intraocular lenses for presbyopia correction: past, present, and future. Curr Opin Ophthalmol. 2012;23:40-6.
11. Tang-Wai DF, Graff-Radford NR, Boeve BF, et al. Clinical, genetic, and neuropathologic characteristics of posterior cortical atrophy. Neurology. 2004;63:1168-74.

12. Lehmann M, Crutch SJ, Ridgway GR, et al. Cortical thickness and voxel-based morphometry in posterior cortical atrophy and typical Alzheimer's disease. Neurobiol Aging. 2011;32:1466-76.

13. Ahmed $\mathrm{S}$, Baker I, Husain $\mathrm{M}$, et al. Memory impairment at initial clinical presentation in posterior cortical atrophy. J Alzheimers Dis. 2016;52:1245-50

14. Renner JA, Burns JM, Hou CE, et al. Progressive posterior cortical dysfunction: a clinicopathologic series. Neurology. 2004;63:1175-80.

15. Kas A, De Souza LC, Samri D, et al. Neural correlates of cognitive impairment in posterior cortical atrophy. Brain. 2011;134:1464-78.

16. Seguin J, Formaglio M, Perret-Liaudet $\mathrm{A}$, et al. CSF biomarkers in posterior cortical atrophy. Neurology. 2011;76:1782-8.

17. Rosenbloom MH, Alkalay A, Agarwal N, et al. Distinct clinical and metabolic deficits in PCA and AD are not related to amyloid distribution. Neurology. 2011;76:1789-96.

18. Formaglio M, Costes $\mathrm{N}$, Seguin J, et al. In vivo demonstration of amyloid burden in posterior cortical atrophy: a case series with PET and CSF findings. J Neurol. 2011;258:1841-51.

19. de Souza LC, Lamari F, Belliard S, et al. Cerebrospinal fluid biomarkers in the differential diagnosis of Alzheimer's disease from other cortical dementias. J Neurol Neurosurg Psychiatry. 2011;82:240-6

20. Peng G, Liu P, He F, Luo B. Posterior cortical atrophy as a primary clinical phenotype of corticobasal syndrome with a progranulin gene rs5848 Tा genotype. Orphanet J Rare Dis. 2016;11:13.

21. Alladi S, Xuereb J, Bak T, et al. Focal cortical presentations of Alzheimer's disease. Brain. 2007:130:2636-45.

22. Caroppo P, Belin C, Grabli D, et al. Posterior cortical atrophy as an extreme phenotype of GRN mutations. JAMA Neurol. 2015;72:224-8

23. Goldstein MA, Ivanov I, Silverman ME. Posterior cortical atrophy: an exemplar for renovating diagnostic formulation in neuropsychiatry. Compr Psychiatry. 2011;52:326-33.

24. Ridha BH, Crutch $S$, Cutler $D$, et al. A double-blind placebo-controlled cross-over clinical trial of DONepezil in Posterior cortical atrophy due to underlying Alzheimer's Disease: DONIPAD study. Alzheimers Res Ther. 2018;10:44.

25. Crutch SJ, Lehmann M, Schott JM, et al. Posterior cortical atrophy. Lancet Neurol. 2012;11:170-8.

26. Levine DN, Lee JM, Fisher CM. The visual variant of Alzheimer's disease: a clinicopathologic case study. Neurology 1993:43:305.

27. Aharon-Peretz J, Israel O, Goldsher D, Peretz A. Posterior cortical atrophy variants of Alzheimer's disease. Dement Geriatr Cogn Disord. 1999:10:483-7.

28. Chew SSL, Kerr NM, Danesh-Meyer HV. Giant cell arteritis. J Clin Neurosci. 2009;16:1263-8.

29. Mahr A, Aouba A, Richebé P, Gonzalez-Chiappe S. Epidemiology and natural history of giant cell arteritis. Rev Med Interne. 2017;38:663-9.

30. Rubenstein E, Maldini C, Gonzalez-Chiappe S, et al. Sensitivity of temporal artery biopsy in the diagnosis of giant cell arteritis: a systematic literature review and meta-analysis. Rheumatology (Oxford). 2020;59:1011-20

31. Mahr A, Paccalin M, Hachulla E, et al. FRI0283 presentation and management of giant cell arteritis in a real-world setting (ARTEMIS study). Ann Rheum Dis. 2019;78:822-3.

32. Baldursson Ó, Steinsson K, Björnsson J, Lie JT. Giant cell arteritis in Iceland. An epidemiologic and histopathologic analysis. Arthritis Rheum. 1994;37:1007-12.

33. Willkinson IMS. Arteries of the head and neck in giant cell arteritis. 
Arch Neurol. 1972;27:378-91.

34. De Smit E, O'Sullivan E, Mackey DA, Hewitt AW. Giant cell arteritis: ophthalmic manifestations of a systemic disease. Graefes Arch Clin Exp Ophthalmol. 2016;254:2291-306.

35. Weyand $\mathrm{CM}$, Goronzy JJ. Medium- and large-vessel vasculitis. N Eng J Med. 2003;349:160-9.

36. Salvarani C, Cantini F, Boiardi L, Hunder GG. Polymyalgia rheumatica and giant-cell arteritis. N Eng J Med. 2002;347:261-71.

37. Tovilla-Canales JL. Ocular manifestations of giant cell arteritis. Curr Opin Ophthalmol. 1998;9:73-9.

38. Rahman W, Rahman FZ. Giant cell (temporal) arteritis: an overview and update. Surv Ophthalmol. 2005;50:415-28.

39. Hazleman B. Laboratory investigations useful in the evaluation of polymyalgia rheumatica (PMR) and giant cell arteritis (GCA). Clin Exp Rheumatol. 2000:18(4 Suppl. 20):S29-31.

40. Buttgereit F, Dejaco C, Matteson EL, Dasgupta B. Polymyalgia rheumatica and giant cell arteritis: a systematic review. JAMA 2016;315:2442-58.

41. Kyle V, Cawston TE, Hazleman BL. Erythrocyte sedimentation rate and $\mathrm{C}$ reactive protein in the assessment of polymyalgia rheumatica/giant cell arteritis on presentation and during follow up. Ann Rheum Dis. 1989:48:667-71

42. Gabriel SE, Espy M, Erdman DD, et al. The role of parvovirus B19 in the pathogenesis of giant cell arteritis: a preliminary evaluation. Arthritis Rheum. 1999:42:1255-8.

43. Nordborg C, Nordborg E, Petursdottir V, et al. Search for varicella zoster virus in giant cell arteritis. Ann Neurol. 1998;44:413-4.

44. Rimenti G, Blasi F, Cosentini R, et al. Temporal arteritis associated with Chlamydia pneumoniae DNA detected in an artery specimen. J Rheumatol. 2000:27:2718-20

45. Ma-Krupa W, Kwan M, Goronzy JJ, Weyand CM. Toll-like receptors in giant cell arteritis. Clin Immunol. 2005;115:38-46.

46. Samson M, Corbera-Bellalta M, Audia S, et al. Recent advances in our understanding of giant cell arteritis pathogenesis. Autoimmun Rev. 2017;16:833-44.

47. Mizen TR. Giant cell arteritis: diagnostic and therapeutic considerations. Ophthalmol Clin North Am. 1991;4:547-56.

48. Vinit J, Bielefeld P, Muller G, Besancenot JF. Efficacy of tocilizumab in refractory giant cell arteritis. Joint Bone Spine. 2012:79:317-8.

49. Ișık M, Kilıç L, Doğan I, Calgüneri M. Tocilizumab for giant cell arteritis: an amazing result. Rheumatol Int. 2013;33:2961-2.

50. Liu GT, Glaser JS, Schatz NJ, Smith JL. Visual morbidity in giant cell arteritis: clinical characteristics and prognosis for vision. Ophthalmology. 1994;101:1779-85.

51. Danesh-Meyer H, Savino PJ, Gamble GG. Poor prognosis of visual outcome after visual loss from giant cell arteritis. Ophthalmology. 2005;112:1098-103.

52. Chan $\mathrm{CC}$, Paine M, O'Day J. Steroid management in giant cell arteritis. Br J Ophthalmol. 2001;85:1061-4.

53. Foroozan R, Deramo VA, Buono LM, et al. Recovery of visua function in patients with biopsy-proven giant cell arteritis. Ophthalmology. 2003;110:539-42.

54. Patel SH, Cunnane ME, Juliano AF, et al. Imaging appearance of the lateral rectus-superior rectus band in 100 consecutive patients without strabismus. AJNR Am J Neuroradiol. 2014;35:1830-5

55. Pula JH, Kwan K, Yuen CA, Kattah JC. Update on the evaluation of transient vision loss. Clin Ophthalmol. 2016;10:297.

56. Warren NM, Burn DJ. Progressive supranuclear palsy. Pract Neurol. $2007: 7: 16-23$

57. Bower JH, Maraganore DM, MCDonnell SK, Rocca WA. Incidence of progressive supranuclear palsy and multiple system atrophy in Olmsted County, Minnesota, 1976 to 1990. Neurology. 1997:49:1284-8.

58. Litvan I, Mangone CA, McKee A, et al. Natural history of progressive supranuclear palsy (Steele-Richardson-Olszewski syndrome) and clinical predictors of survival: a clinicopathological study. J Neurol Neurosurg Psychiatry. 1996;60:615-20.

59. Hauw JJ, Daniel SE, Dickson D, et al. Preliminary NINDS neuropathologic criteria for Steele-Richardson-Olszewsk syndrome (progressive supranuclear palsy). Neurology. 1994;44:2015-9.

60. Litvan I, Agid Y, Calne D, et al. Clinical research criteria for the diagnosis of progressive supranuclear palsy (Steele-Richardson-Olszewski syndrome): report of the NINDS-SPSP international workshop. Neurology. 1996;47:1-9.

61. Litvan I, Agid Y, Jankovic J, et al. Accuracy of clinical criteria for the diagnosis of progressive supranuclear palsy (Steele-Richardson-Olszewski syndrome). Neurology. 1996:46:922-30.

62. Dickson DW, Ahmed Z, Algom AA, et al. Neuropathology of variants of progressive supranuclear palsy. Curr Opin Neurol. 2010;23:394-400.

63. Armstrong MJ. Progressive supranuclear palsy: an update Curr Neurol Neurosci Rep. 2018:18:12.

64. Schrag A, Good CD, Miszkiel K, et al. Differentiation of atypical parkinsonian syndromes with routine MRI. Neurology. 2000;54:697-702.

65. Caparros-Lefebvre D, Golbe LI, Deramecourt V, et al. A geographical cluster of progressive supranuclear palsy in northern France. Neurology. 2015;85:1293-300.

66. Fujioka S, Algom AA, Murray ME, et al. Similarities between familia and sporadic autopsy-proven progressive supranuclear palsy. Neurology. 2013:80:2076-8.

67. Fujioka S, Van Gerpen JA, Uitti RJ, et al. Familial progressive supranuclear palsy: a literature review. Neurodegener Dis. 2014;13:180-2.

68. Im SY, Kim YE, Kim YJ. Genetics of progressive supranuclear palsy. J Mov Disord. 2015;8:122-9.

69. Rehman HU. Progressive supranuclear palsy. Postgrad Med 2000;76:333-6

70. Warren NM, Burn DJ. Progressive supranuclear palsy. Pract Neurol 2007;7:16-23

71. Golbe LI. Progressive supranuclear palsy. Semin Neurol. 2014;34:151-9.

72. Hattenhauer MG, Leavitt JA, Hodge DO, et al. Incidence of nonarteritic anterior ischemic optic neuropathy. Am J Ophthalmol. 1997;123:103-7

73. Chen J. Trying to understand nonarteritic anterior ischemic optic neuropathy through big data. Ophthalmology. 2016;123:2442-3.

74. Preechawat P, Bruce BB, Newman NJ, Biousse V. Anterior ischemic optic neuropathy in patients younger than 50 years. Am J Ophthalmol. 2007;144:953-60.

75. Newman NJ, Dickersin K, Kaufman D, et al. Characteristics of patients with nonarteritic anterior ischemic optic neuropathy eligible for the Ischemic Optic Neuropathy Decompression Trial. Arch Ophthalmol. 1996;114:1366-74.

76. Hayreh SS, Zimmerman MB. Nonarteritic anterior ischemic optic neuropathy: natural history of visual outcome. Ophthalmology. 2008; 115:298-305.

77. Rizzo JF, Lessell S. Optic neuritis and ischemic optic neuropathy: overlapping clinical profiles. Arch Ophthalmol. 1991;109:1668-72

78. Mojon DS, Hedges TR, Ehrenberg B, et al. Association between sleep apnea syndrome and nonarteritic anterior ischemic optic neuropathy. Arch Ophthalmol. 2002;120:601-5.

79. Li J, MCGwin G, Vaphiades MS, Owsley C. Non-arteritic anterio ischaemic optic neuropathy and presumed sleep apnoea syndrome screened by the sleep apnea scale of the sleep disorders questionnaire (SA-SDQ). Br J Ophthalmol. 2007;91:1524-7.

80. Purvin VA. Anterior ischemic optic neuropathy secondary to interferon alfa. Arch Ophthalmol. 1995:113:1041-4.

81. Gupta R, Singh $S$, Tang R, et al. Anterior ischemic optic neuropathy caused by interferon alpha therapy. Am J Med. 2002;112:683-4.

82. Danesh-Meyer HV, Levin LA. Erectile dysfunction drugs and risk of anterior ischaemic optic neuropathy: casual or causal association? Br J Ophthalmol. 2007;91:1551-5.

83. Flores-Reyes E, Hoskens K, Mansouri K. Optic nerve head drusen: imaging using optical coherence tomography angiography. I Glaucoma. 2017:26:845-9.

84. Gittinger JW Jr, Lessell S, Bondar RL. Ischemic optic neuropathy associated with optic disc drusen. J Clin Neuroophthalmol. 1984;4:79-84

85. Newman WD, Dorrell ED. Anterior ischemic optic neuropathy associated with disc drusen. J Neuroophthalmol. 1996;16:7-8.

86. Knox DL. Slowly progressive ischemic optic neuropathy. Ophthalmology. 1971;75:1065-8.

87. Hayreh SS, Zimmerman MB. Ocular arterial occlusive disorders and carotid artery disease. Ophthalmol Retina. 2017:1:12-8.

88. Moghimi S, Afzali M, Akbari M, et al. Crowded optic nerve head evaluation with optical coherence tomography in anterior ischemic optic neuropathy. Eye. 2017;31:1191-8.

89. Levin LA, Louhab A. Apoptosis of retinal ganglion cells in anterio ischemic optic neuropathy. Arch Ophthalmol. 1996;114:488-91.

90. Nazari H, Berry S, Sadaka A, Lee AG. The challenge of managing NAION. 2017. Available at: www.retina-specialist.com/article/thechallenge-of-managing-naion (accessed May 14, 2020).

91. Atkins EJ, Bruce BB, Newman NJ, Biousse V. Treatment of nonarteritic anterior ischemic optic neuropathy. Surv Ophthalmol. 2010;55:47-63.

92. Bernstein SL, Johnson MA, Miller NR. Nonarteritic anterior ischemic optic neuropathy (NAION) and its experimental models. Prog Retin Eye Res. 2011;30:167-87. 